50 лет назад автор статьи, которому 28 апреля исполняется 75, познакомился с Н.И. Либаном.

А.В. Корнеев (Москва, Россия)

Ученик Николая Ивановича Либана

A.V. Korneev (Moscow, Russia)

\title{
Disciple of Nikolai Ivanovich Liban
}

Если Бог пошлет мне достойных читателей, то, может быть, для них будет любопытно узнать, каким образом я стал историком литературы. - Почти так начинает пушкинский герой Иван Петрович Белкин «Историю села Горюхина», и я стараюсь следовать его примеру.

Мне было восемь лет, когда я увидел на телеэкране Ираклия Андроникова и услышал его знаменитый рассказ «Загадка Н.Ф.И.» . И хотя я мало что тогда понял два года спустя в доме появится только что вышедшая книжка Андроникова, где будет и «Загадка Н.Ф.И.», и тогда многое для меня станет яснее, - но с уверенностью скажу: любовь к XIX столетию и его литературе зародилась в моем сердце именно в то время. А вместе с ней я возымел «охоту рыться в хронологической пыли» и интерес к архивным поискам, которые приведут меня на филологический факультет.

Хотя я мечтал о Московском университете, с мечтой пришлось расстаться. Когда, окончив одиннадцать классов, получил аттестат зрелости, мне уже исполнилось восемнадцать. Если бы я не поступил в вуз тем летом, то в следующем году меня ждал бы призыв в армию. А в 1964 г., когда окончил школу, поток абитуриентов был особенно велик: одновременно получили аттестаты окончившие как десять, так и одиннадцать классов. Поэтому я выбрал вуз с наиболее скромным названием - Московский областной педагогический институт, пытаясь уверить себя, что программа там не очень отличается от университетской.

\footnotetext{
${ }^{1}$ Позднее, когда я сам начал заниматься архивными поисками, то понял, что полностью верить литературоведческим рассказам Андроникова нельзя, поскольку иные подробности его разысканий явно рассчитаны на дилетантов. Так, в «Загадке Н.Ф.И.» в поисках сведений, за кого Наталия Иванова вышла замуж, если верить автору, ему пришлось потратить много дней, перелистывая все родословные книги, какие только были в библиотеке Пушкинского Дома, сложив их штабелями возле стола. Однако искомую фамилию Андроников нашел отнюдь не в каком-то забытом фолианте, а в превосходно известном историкам «Родословном сборнике русских дворянских фамилий» В.В. Руммеля и В.В. Голубцова, с которого и следовало начинать поиск, и где в именном указателе фамилия Ивановых указана только пять раз, а значит, поиск занял всего лишь несколько минут.
}

Stephanos \#2 (46) http://stephanos.ru 
О поэте с очень русскими именем и отчеством и двойной немецкой фамилией Иван Иванович Гольц-Миллер, чья недолгая жизнь пришлась на 60-е гг. XIX столетия, - я узнал впервые на первом курсе. Тогда под впечатлением литературоведческих рассказов Ираклия Андроникова, страстно влюбленный в XIX в., я мечтал об архивных разысканиях. О своем пристрастии я поведал преподавателю, читавшему курс «Введение в литературоведение», и попросил порекомендовать тему, которая предполагала такие поиски. Он назвал несколько имен малоизученных поэтов русских прошлого века.

Через несколько дней в читальном зале Ленинской библиотеки я просмотрел рекомендованные книги и понял, что менее всего известно о Гольц-Миллере: единственная тонкая книжка его стихов была выпущена в 1930 г. издательством Всесоюзного общества политкаторжан и ссыльнопоселенцев под названием «Поэт-революционер И.И. Гольц-Миллер», объединив 32 стихотворения, напечатанные при его жизни, и 3 произведения, опубликованные уже после его смерти. Автор статьи о поэте, напечатанной за год до этого в журнале того же общества «Каторга и ссылка», с грустью признавал: «Биографические сведения о Гольц-Миллере не отличаются особым обилием и богатством». Завершалась статья словами: «Надо разыскать неизданные произведения Гольц-Миллера... Надо вырвать из забвения творчество талантливого представителя одной из самых героических эпох революционной истории»

Составители сборника «Поэт-революционер И.И. Гольц-Миллер» писали: «Отец поэта сообщал, что после его сына осталось до 70 стихотворений. В настоящее время нам удалось собрать только 34, т. е. только половину литературного наследства Гольц-Миллера. Другую половину, по-видимому, приходится считать безвозвратно погибшей». Однако несколько лет спустя литературовед И.Г. Ямпольский обнаружил в фондах Института русской литературы (Пушкинский дом) подготовленный к печати отцом поэта рукописный сборник стихотворений Гольц-Миллера. Выбрав из числа неизданных 14 стихотворений, представлявших, на его взгляд, наибольший интерес, Ямпольский опубликовал их в 1936 г. в «Литературном наследстве». Остальные оставались ненапечатанными и по-прежнему находились в рукописном сборнике, хранившемся в Ленинграде в Пушкинском доме.

Хотя фамилия поэта была мне неизвестна, однако одно из его стихотворений оказалось знакомым. Положенное еще при жизни поэта на музыку, оно стало известной революционной песней - об узнике, отважившемся на побег и предпочевшем гибель заключению в неволе, каждая строфа которой завершалась возгласом «слу-шай!», которым перекликались окружавшие тюрьму часовые:

\section{Слушай!}

Как дело измены, как совесть тирана

Осенняя ночка черна...

Черней этой ночи встает из тумана

Видением мрачным тюрьма.

Кругом часовые шагают лениво;

В ночной тишине, то и знай,

Как стон, раздается протяжно, тоскливо:

- Слу-шай!..

К окончанию второго курса я изучил всю литературу, где упоминалась фамилия Гольц-Миллера, и достаточно хорошо знал его биографию. К сожалению, этого я не мог сказать о его творчестве. По-прежнему мне были известны только 
стихи, помещенные в тонкой книжке «Поэт-революционер И.И. Гольц-Миллер» и опубликованные шесть лет спустя в «Литературном наследстве». И, перейдя на третий курс, в летние каникулы я поехал в город на Неве. В отделе рукописей Пушкинского дома мне выдали толстую продолговатую тетрадь с пожелтевшими страницами, более похожую форматом на альбом.

На титульной странице написано:

Стихотворения Ив. Гольц-Миллера

Если долго сдержанные муки, Накипев, под сердце подойдут, Я пишу...

\section{Некрасов}

Скептически наблюдая, как я начал переписывать стихотворения в тетрадь, сотрудница отдела остановила мой порыв. Оказалось, прежде чем начать подобную работу, нужно было получить разрешение заведующего отделом рукописей. Как я узнал, им был маститый пушкинист Николай Васильевич Измайлов. Под диктовку сотрудницы я написал заявление на его имя. В сокращенном виде оно выглядело примерно так: «Доктору филологических наук... от студента... Прошу разрешить мне ознакомиться со стихами Гольц-Миллера и скопировать их для подготовки курсовой работы» - увы, более весомой причины я привести не мог. «Укажите, на каком вы курсе», - потребовала сотрудница. Только что переведенный на третий курс, я смиренно приписал «от студента третьего курса», понимая, сколь ничтожно это будет выглядеть в глазах маститого ученого. «Но вы не написали, какие именно стихотворения вы хотели бы скопировать», - резонно заметила сотрудница. «Но я бы хотел... все стихотворения...» - окончательно смутившись, пробормотал я, сознавая, сколь странно выглядит моя просьба. «Все?! - изумлению моей собеседницы не было границ. - Но зачем вам это - ведь многие стихи Гольц-Миллера уже опубликованы». - «Но профессор Ямпольский при публикации части стихов в «Литнаследстве» отмечал, что в напечатанных при жизни поэта по сравнению с неопубликованными имеются разночтения, которые представляют интерес...» - попытался объяснить я нелепость своей просьбы. «Хорошо, - смилостивилась сотрудница, - я сегодня же передам ваше заявление Николаю Васильевичу, а как решит он, об этом вы узнаете завтра».

С нетерпением дождался я следующего дня, терзаясь в раздумьях: разрешат мою просьбу или нет. Прихожу на следующий день в Пушкинский дом. Смущенно спрашиваю сотрудницу, прочитал ли Николай Васильевич мое заявление. «Да, прочитал и написал резолюцию, с которой вы можете ознакомиться», - отвечает она, подавая мне мое заявление. Что я ожидал увидеть? Всего одно слово, написанное Измайловым - «разрешаю», или на худой конец - «отказать». Однако резолюция, начертанная маститым пушкинистом, оказалась гораздо более пространной: «Не возражаю, но считаю, что студенту третьего курса следовало бы заняться чем-либо более полезным, чем копированием всех стихов Гольц-Миллера». Эту резолюцию я запомнил до конца жизни. Тогда меня интересовал лишь результат - в моей просьбе не было отказано. И только позднее, помимо этого, я ощутил в пространной резолюции нечто еще - некоторое высокомерие маститого пушкиниста как к стихам какого-то забытого поэта, так и к некоему студенту третьего курса, интересующемуся его творчеством. 
Тема, выбранная мной на первом курсе, стала основой курсовой и дипломной работ. Она могла бы стать и основой диссертации... если бы мой научный руководитель не отказался бы от меня. Он не стал спорить с завкафедрой, довольно вредной дамой, которая усиленно проталкивала в аспирантуру своих учеников. В результате после получения диплома мне пришлось обивать пороги кафедр других вузов в тщетной надежде поступить в аспирантуру или хотя бы прикрепиться к ней.

Что я представлял собой тогда? Бесхитростного юношу, знания которого несколько превышали курс пединститута, но были далеки от тех, что давал университет.

Только колоссальная наивность заставила меня без чьей-либо рекомендации прийти с той же целью на прием к заведующему кафедрой русской литературы МГУ В.И. Кулешову. Как и следовало ожидать, разговор с ним ни к чему не привел. Выйдя из его кабинета, я увидел только что пришедшего на кафедру элегантно одетого пожилого человека. Секретарь почтительно назвала его «Сергей Михайлович», и я понял, что это профессор Бонди - я читал о нем очерк И. Андроникова «Замечательный пушкинист» и запомнил имя и отчество знаменитого ученого. На мое счастье, на кафедре в этот вечерний час никого не было, и Бонди никто не отвлек неизбежным разговором. Набравшись смелости, я попросил его уделить мне две минуты и рассказал о своих бедах. Он сочувственно выслушал меня и порекомендовал обратиться к Николаю Ивановичу Либану.

Так благодаря этой рекомендации началось мое знакомство с замечательным ученым и педагогом. В отличие от других учеников Николая Ивановича, мне не довелось в студенческие годы быть слушателем его лекций и участником семинаров. Наше общение произошло позднее, но продолжалось почти четыре десятилетия.

Либан был человеком великой души и огромной щедрости. Сколько времени не только в университете, но и вне его он совершенно бескорыстно уделял своим ученикам и делился богатством знаний! За годы нашего знакомства я имел возможность убедиться в этом великое множество раз.

Уроки Николая Ивановича я помню до сих пор. Помню его замечания - не только по смыслу, но и по стилю написанного. Он был великолепным стилистом, замечательно чувствовал слово. (Думаю, со мною согласятся многие его ученики, писавшие под руководством Либана статьи, диссертации, монографии.) Сколько раз, сидя в старинном кресле у овального стола, я читал моему учителю написанное и выслушивал критические замечания. Вот я читаю ему очередной опус, и он останавливает меня - его коробит услышанная фраза. Я сознаюсь, что она принадлежит не мне, а позаимствована из книги, написанной неким профессором. Николай Иванович смеется: «Нашли у кого списывать!»

Тогда эти слова показались мне странными. Для меня в то время, говоря фразой сатиры И.И. Дмитриева, которую вспомнил А.С. Пушкин в одной из заметок цикла «Опровержение на критики», печатный лист казался едва ли не святым. Разве мог профессор, доктор наук, автор солидной книги написать глупость?! Это казалось мне невероятным. Однако пройдет несколько лет, и из книги, написанной другим профессором, я узнаю, что тургеневский Базаров препарировал не лягушек, как полагал я, а кошек! А годы спустя, рецензируя статьи, написанные для словаря «Русские писатели», сам буду отмечать достойные внимания выражения в писаниях некоторых мужей науки. 
Мою тему о Гольц-Миллере Николай Иванович воспринял с большим интересом, без малейшего высокомерия, в противовес гонору маститого пушкиниста. Совет последнего «заняться чем-либо более полезным», чем копирование стихов забытого поэта, он назвал абсурдным и напомнил слова А.П. Чехова: «В литературе маленькие чины так же необходимы, как и в армии». При непосредственном участии Либана была подготовлена большая подборка стихов Гольц-Миллера все неизвестные ранее произведения поэта, которая была опубликована автором этих строк в 1980 г. в ленинградском академическом журнале «Русская литература». Думаю, раскрыв очередной номер журнала, Н.В. Измайлов смог увидеть мою публикацию. Вспомнил ли он свою давнюю резолюцию, рекомендовавшую студенту третьего курса заняться более полезным, чем копированием стихов Гольц-Миллера?

С неменьшим интересом воспринял Николай Иванович перипетии скитальческой жизни поэта-революционера. Узнав от меня, что в архиве Пушкинского дома находятся непрочитанные письма, написанные отцом поэта, которыми я в свое время пренебрег, Николай Иванович настоятельно советовал мне ознакомиться с ними и вообще узнать больше о семействе Гольц-Миллера. Я последовал совету Учителя; в следующий мой приезд в Ленинград ${ }^{1}$ раскрыл в Пушкинском доме письма - и не пожалел об этом.

Казалось, я достаточно хорошо знаю биографию Гольц-Миллера, ведь мной изучена вся литература, где упоминалась эта фамилия. Более того, в фонде «III Отделения собственной его императорского величества канцелярии» Центрального государственного архива Октябрьской революции (ныне Государственный архив Российской Федерации) я просмотрел секретную переписку двух высших сановников Российской империи: главного начальника III Отделения (он же шеф жандармов) и министра внутренних дел, в которой на протяжении десяти лет статс-секретари и генерал-адъютанты удостаивали вниманием скромного молодого человеке, бывшего студента Московского университета, состоявшего под полицейским надзором, замененным секретным наблюдением. Хотя против него не было никаких улик, кроме общего рода обвинений в «дурном направлении и нигилистических убеждениях», его влияние на студенческую молодежь они считали настолько опасным, что запрещали пребывание во всех университетских городах. И все же, полагая, что хорошо знаю биографию Гольц-Миллера, я ошибался.

Во время первого посещения отдела рукописей Пушкинского дома мне выдали в числе других материалов Гольц-Миллера и письма, адресованные редакторам журналов «Русская старина» и «Вестник Европы». Как выяснилось, произошла досадная ошибка: они были написаны не поэтом, а его отцом, имевшим одинаковые с сыном имя и отчество. Тогда я не стал просматривать эти материалы. И вот теперь этот момент настал.

Изучая пятнадцать лет творчество Гольц-Миллера, я свыкся с мыслью, что поэт происходит из обрусевших немцев. Подобные примеры хорошо известны в отечественной литературе. Достаточно вспомнить, что два близких друга Пушкина, еще по лицею, русские поэты, носили немецкие фамилии.

Однако смущало обстоятельство, что и отец Гольц-Миллера, и сам поэт в своих письмах подчеркивали, что они - русские. «По рождению и по духу - русский, хотя и с немецким прозванием...»- писал первый М.М. Стасюлевичу. Смущало ${ }^{1}$ В то время, работая в редакции железнодорожной газеты, я ежегодно во время отпуска бывал в городе на Неве. 
также стихотворение Гольц-Миллера «С верой за дело!», опубликованное в 1867 г. в издававшемся в Вене журнале «Славянская заря», имевшее подзаголовок «посвящается славянской молодежи»; в нем автор горячо поддерживал идею объединения славянских народов в единое государство, - такая мысль вряд ли была бы столь близко к сердцу принята немцем.

Подобные размышления пришли на память, когда я начал читать письма отца поэта. Из обстановки разночинной интеллигенции 1860-х гг. мне пришлось перенестись в первую четверть ХІХ столетия - в мир аристократии и поместного дворянства. Уже начало письма Гольц-Миллера-старшего к известному историку, редактору-издателю журнала «Русская старина» М.И. Семевскому, написанного 17 февраля 1871 г., заинтриговало меня. Предлагая для публикации свои воспоминания, он писал: «Затем мне еще остается высказать главное и самое для меня тягостное, и это я решаюсь сделать собственно потому, что мне жить уже немного остается (мне 65 л[ет] и здоровье мое убито, а “мертвые сраму не имут"). Хотя фамилия моя немецкая, но я имел несчастие родиться от русского графа и девицы старинной дворянской фамилии, притом не развратницы какой-нибудь или содержанки, и значит незаконно?!»

Как сообщалось далее в письме, его автор родился в 1806 г. в Москве. Мать автора скончалась при родах, и он воспитывался в Москве в семье повивальной бабки Гольц-Миллер и ее мужа, отставного поручика прусской службы, не имевших детей. «Когда старики Гольц-Миллеры скончались обои на одной неделе... меня взяла к себе на воспитание, или лучше сказать - на прокормление помещица Владим[ирской] губ[ернии] Бехтеева, знавшая тайну моего рождения и сообщившая мне о ней, когда мне было уже 18 лет. Она мне также говорила, что знала хорошо и любила мою мать. В доме Бехтеевых, в роскошном селе Дубках я был выращен, но не воспитан - воспитание мое было сиротское».

Более подробно о своем пребывании в доме Бехтеевых Гольц-Миллер-старший рассказывал в главе своих воспоминаний, также присланной редактору «Русской старины», озаглавленной «Село Дубки и мое в них воспитание (1814-1821)» и начинавшейся словами: «Таким образом, после скромной и тихой, до 8 лет, жизни в доме немки-акушерки я вдруг, неожиданно, попал в роскошный и шумный дом русского барина тогдашних времен».

И сами Бехтеевы, которых автор воспоминаний с горькой иронией именует «благодетелями», и воспитанники гувернера их сына француза Лафоржа, содержавшего в Дубках нечто вроде пансиона, и прислуга обращались с мальчиком грубо и пренебрежительно. «Благодетели мои имели обыкновение рекомендовать меня всякому, в присутствии прислуги, так: “Это бедный сирота, без роду и племени, которого мы из жалости призрели”. Смекая из этого, что я, должно быть, подкидыш, лакейство обращалось со мной очень бесцеремонно и нередко даже меня колотило... Жаловаться я боялся, потому что это всегда приписывалось неуживчивости и строптивости моего нрава».

Автор воспоминаний упоминает об образовании, полученном им в отроческие годы. В виде благодеяния Бехтеевы позволяли мальчику посещать занятия в пансионе Лафоржа, однако проводились они столь отрывочно и несистематично, что говорить о серьезном образовании не приходится. Кроме того, как с иронией отмечал Гольц-Миллер-старший, закону Божию учила его старуха-ключница, заставляя 
читать молитвы утром и вечером, пьяница-конторщик обучал письму, а арифметику он проходил практически, считая шары, когда Бехтеев играл на биллиарде.

По иронии судьбы Гольц-Миллер с детских лет находился в аристократическом обществе. В доме Бехтеевых он видел семейство дочери А.В. Суворова графини Н.А. Зубовой и играл в лошадки с ее младшим сыном Валерианом. Гольц-Миллер слушал рассказы Бехтеева о многих видных деятелях трех царствований, которых тот, начав служить еще при Екатерине II, хорошо знал, в том числе о М.M. Сперанском (село Черкутино, где он родился, находилось поблизости от имения Бехтеевых).

К письму Гольц-Миллера-старшего был приложен крайне любопытный документ - копия свидетельства, составленного Бехтеевым и его знакомыми, с которым юноша начал самостоятельную жизнь:

\section{Свидетельство}

Объявитель сего Иван Иванов Гольц-Миллер, сын прусской службы поручика Гольц-Миллера, после смерти коего остался малолетним и наконец обучался разным наукам в доме надворного советника Алексея Алексеевича Бехтеева, читать, писать и говорить по-французски и русски умеет, арифметике и географии учился; от роду ему 16 лет; не быв ни в каком сословии записанным, желает вступить в статскую службу [...]».

Вернувшись в Москву, я был рад рассказать Николаю Ивановичу о том, что выяснилось из писем отца поэта. Либан с большим интересом выслушал меня, и мы пришли к выводу продолжать разыскания, восстанавливая необычную судьбу этого человека.

Год спустя, в новый мой приезд в Ленинград, архивные поиски переместились на другой берег Невы, в Центральный государственный исторический архив СССР (ныне Российский государственный исторический архив).

Поскольку в переписке шефа жандармов и министра внутренних дел студент Гольц-Миллер именовался дворянином, возникал вопрос, как сумел его отец, «не быв ни в каком сословии записанным», достигнуть дворянства. Мы обсуждали различные версии: Гольц-Миллер-старший мог попасть в привилегированное сословие или доказав, что он действительно сын поручика прусской службы, или дослужившись до чина коллежского асессора (в 60-е годы он имел этот чин, занимая должность секретаря Минского губернского акцизного управления). Конкретный ответ на это вопрос могли дать архивные документы.

С волнением я раскрыл папку с надписью «Правительствующего сената департамента герольдии дело о дворянстве рода Гольц-Миллеров». Если поиски в архиве Пушкинского дома завершились отысканием свидетельства, с которым отец поэта начал самостоятельную жизнь, то материалы этого дела, в частности его формулярный список, копией которого оно начиналось, позволяли проследить, как она проходила.

Спустя четыре дня, после того исконно русский человек «официально составленным документом произведен был в немцы», как с горькой иронией напишет Гольц-Миллер-старший М.М. Стасюлевичу, он начинает самостоятельную жизнь. Складывалась она нелегко: внебрачный сын родителей, принадлежавших к старинным дворянским фамилиям, занимавших высокое положение в обществе, он сам, без чьей-либо помощи, должен был добиваться места в жизни.

10 ноября 1820 г. Гольц-Миллер-старший начал службу в скромной должности канцелярского служителя в отделении питейного сбора Владимирской казенной палаты. Год спустя - 1 декабря 1821 г. - он был переведен в канцелярию вла- 
димирского губернатора графа П.И. Апраксина, в доме которого жил «в качестве облагодетельствованного сироты», где, по его собственным словам, «встречал немало знаменитых людей тогдашней эпохи». Редакции «Русской старины» отец поэта предложил свои воспоминания о встречах в доме Апраксина с графом Разумовским, проведшем почти двадцать лет «в самом строгом заточении в Суздальском Спасо-Евфимьевском монастыре», из которого он был освобожден по ходатайству губернатора. В мире этих людей Гольц-Миллер постоянно ощущал свою неполноправность и чувствовал себя в нем отверженным. Достаточно сказать, что в доме Апраксина его поселили вместе с Разумовским, чтобы тому «не было так скучно». Подобное соседство с человеком, перенесшим долгое заключение, отразившееся на его психическом состоянии, представляло немалую опасность для юноши: во время одного из припадков помешательства граф чуть было не ударил его ножом.

Вновь обратившись к формулярному списку, мы узнаем, что только через четыре года после начала службы - 31 декабря 1824 г. - Гольц-Миллер получает первый классный чин коллежского регистратора. 26 апреля 1826 г. он был уволен по прошению из канцелярии владимирского губернатора, а 4 мая определен в канцелярию нижегородского, казанского, симбирского, саратовского и пензенского генерал-губернатора. 8 января 1828 г. произведен в губернские секретари.

Как свидетельствуют дальнейшие записи в формулярном списке, молодой человек решается на крутой поворот в судьбе: «не быв ни в каком сословии записанным», видимо, тяготясь неопределенностью своего положения, он решает добиться причисления к привилегированному сословию, дворянству, и с этой целью увольняется из гражданского ведомства для определения в военную службу - первый же офицерский чин давал право на потомственное дворянство.

13 октября 1828 г. Гольц-Миллер поступает фейерверкером (так в артиллерии назывались унтер-офицеры) 4-го класса 1-й батарейной роты 13-й артиллерийской бригады. С началом польской кампании он в числе поступивших на укомплектование артиллерии действующей армии был определен в 4-ю батарейную роту 23-й артиллерийской бригады. Гольц-Миллер принимает участие в военных действиях, в частности, в переправе через реку Буг и взятии крепости Замостье 8 октября 1831 г. Поочередно получает звание фейерверкера 3-го и 2-го классов. До возвращения в пределы России (по 17 мая 1832 г.) значится находящимся в походах.

23 февраля 1834 г. Гольц-Миллер становится офицером - он получает чин прапорщика с определением в один из старейших полков русской армии - Староингерманландский пехотный, а два года спустя - 9 мая 1836 г. - увольняется по прошению от военной службы с награждением чина подпоручика.

Сын родителей, принадлежавших к высшему обществу, вновь становится скромным провинциальным чиновником: военная служба, проходимая в армейском пехотном полку, видимо, не привлекала его. 15 августа 1836 г. он определяется в канцелярию виленского, гродненского, минского и белостокского генерал-губернатора помощником секретаря. Год спустя - 26 августа 1837 г. - его переводят столоначальником в канцелярию Белорусского учебного округа. 10 сентября 1837 г. указом правительствующего сената Гольц-Миллер возвращен в прежний чин губернского секретаря. Человек, тянувший шесть лет солдатскую лямку, участвовавший в сражениях, награжденный «знаком польского ордена за военные достоинства пятого класса», произведенный в офицеры и повышенный в чине при выходе в отставку с военной службы, вновь становится губернским секретарем, чин которого был получен им почти десять лет назад! За эти годы, оставаясь по-прежнему в гражданской 
службе, он был бы повышен на два чина. Единственное преимущество, которого Гольц-Миллер достиг, - право на дворянство. Однако, несмотря на, казалось бы, неоспоримое право, добиться причисления к привилегированному сословию оказалось очень нелегко.

Только будучи человеком семейным, имея двух сыновей, Гольц-Миллер решает ходатайствовать о причислении своего семейства к привилегированному сословию - о внесении его в родословную книгу дворян Ковенской губернии. И хотя он представляет все необходимые для этого документы: копии патента о присвоении ему чина подпоручика и формулярного списка, а также метрические свидетельства о рождении сыновей Ивана и Александра, - в департаменте герольдии ему отказывают. Первоначальная редакция отказа заключалась в том, что «фамилия Гольц-Миллер принадлежит более к числу иностранных фамилий». Однако затем подобная формулировка была вычеркнута: чиновники департамента герольдии сочли ее неубедительной, поскольку множество дворян, имевших иностранные фамилии, тем не менее занимали высокие и даже высшие посты в Российской империи. Новая формулировка отказа гласила: «...поелику удостоверения в том, принадлежит ли он к числу подданных России, со стороны его не представлено и дв[орянским] собранием, как из дела видно, такового требуемо не было».

Отказ департамента герольдии, видимо, не обескуражил привыкшего к различным перипетиям в своей жизни Гольц-Миллера, не замедлившего представить через Ковенское дворянское собрание обоснованное «объяснение», «что он, будучи рожденным в России, крещеным по обрядам православной церкви и находясь на службе 28 лет, до сих пор не считал себя иностранцем... Кроме того, при вступлении благополучно царствующего государя императора на престол в 1825 году, находясь в то время на службе владимирского гражданского губернатора, он учинил в тамошнем правлении присягу на верность подданства, о чем присяжный лист отослан в правительствующий сенат общему собранию с.-петербургских департаментов; из сего явствует, что он и дети его принадлежат к числу природных подданных России, ибо в противном случае, если б он считал себя подданным другой державы и желал таковым остаться, то при вступлении государя императора на престол мог бы не исполнить присяги на верность подданства, объяснив, что он иностранец... Если герольдиею и за сим признано будет, что учиненной им в 1825 году присяги на верность подданства недостаточно, то он во всякое время готов возобновить данную им присягу за себя и за детей своих».

Хорошо продуманный и тщательно аргументированный ответ сыграл положительную роль: указом правительственного сената от 14 февраля 1869 г. было решено «утвердить определение ковенского дворянского собрания о признании в дворянском достоинстве титулярного советника Ивана Гольц-Миллера с сыновьями Иваном и Александром - как правильное».

Необычная судьба Гольц-Миллера наложила отпечаток на формирование его личности. «Вращаясь с малолетства и при особенных совсем условиях в высшем кругу, - пишет Гольц-Миллер М.И. Семевскому, - я многое подмечал, и мой рассказ не может быть односторонним уже собственно потому, что в этом кругу я вращался случайно - как чужой и посторонний, против воли. Я могу указать на совершавшиеся в нем темные дела, на бесчеловечие и все возмутительные безобразия крепостничества, на которые я в детстве насмотрелся».

Убежденный противник крепостного права, он с явной неприязнью относился к аристократии, поместному дворянству и духовенству. Взгляды этого чело- 
века ярко отражены в его неопубликованных воспоминаниях, которые он безуспешно предлагал в журналы «Русская старина» и «Вестник Европы», а также в письмах редакторам этих журналов М.И. Семевскому и М.М. Стасюлевичу. Так, в уже цитировавшемся письме Семевскому Бехтеев характеризуется как «изверг и самодур, каких было немного даже и тогда». О доме, в котором прошли отроческие годы автора письма, он замечает: «Это был прототип тех барских домов минувшего времени, где гордость, мотовство и роскошь шли рука об руку с унижением, невежеством и варварством». В письме Стасюлевичу от 6 января 1874 г. Гольц-Миллер отмечает, как иеромонах Московского Донского монастыря «заметал бородою пыль под биллиардом», а «духовенство за деньги лобызало руки самодура-помещика».

Настало время открыть истинных родителей Гольц-Миллера-старшего. Они названы им в конце письма Семевскому, неоднократно нами цитировавшегося: граф Илья Андреевич Толстой и Екатерина Яковлевна Перфильева. Поскольку, кроме имен, о них ничего не было известно, архивные разыскания, начатые в Ленинграде в отделе рукописей Института русской литературы (Пушкинского дома) АН СССР и продолженные в Центральном государственном историческом архиве СССР, завершились в Москве в отделе рукописных фондов Государственного литературного музея.

В наиболее известном литературоведческом рассказе Ираклия Андроникова «Загадка Н.Ф.И.», написанном в 1930-е гг., есть глава «Знаток старой Москвы», начинающаяся словами: «Был в Москве такой чудесный старичок, Николай Петрович Чулков, - историк и литературовед, великий знаток государственных и семейных архивов XVIII и XIX веков, лучший специалист по истории русского быта, волшебник по части установления служебных и родственных связей великих и не великих русских людей. Уж никто лучше него не мог сказать вам, кто когда родился, кто где жил, кто в каких служил департаментах и полках, кто на ком был женат...».

Просматривая материалы фонда Н.П. Чулкова, я словно слышал голос Николая Петровича, негромкий и слегка дребезжащий, который воспроизвел в телевизионном фильме, также названном «Загадка Н.Ф.И.», благодаря артистическому таланту, Ираклий Андроников:

- Вы совершено правы: Наталия Федоровна Иванова действительно дочь Федора Федоровича, московского драматурга. Правильно и то, что она вышла замуж за Николая Михайловича Обрескова. А вот теперь запишите: у Обресковых была дочь Наталия Николаевна, которая в шестидесятых годах вышла замуж за Сергея Владимировича Голицына. У Голицыных тоже были дочери, родные внучки Наталии Федоровны...

В материалах фонда Н.П. Чулкова, в частности в составленной им родословной дворян Перфильевых, я отыскал Екатерину Яковлевну Перфильеву - смолянку выпуска 1785 г. (выпускницу Смольного института благородных девиц). Там же были указаны ее сестры Евдокия и Елизавета Яковлевны - смолянки выпуска 1782 и 1788 гг., а также их брат Андрей Яковлевич (1765-1823) - морской офицер, бывший одно время адъютантом генерал-поручика И.А. Ганнибала, предка А.С. Пушкина, героя штурма Наварина и Чесменского сражения,

Пред кем средь Чесменских пучин

Громада кораблей вспылала,

И пал впервые Наварин, -

ставшего затем основателем портового города на юге России - Херсона, и сам также завершивший карьеру генералом и возглавивший портовый город уже на севе- 
pe - Архангельск - в должности губернатора. Отцом сестер Перфильевых и их брата в росписи Н.П. Чулкова значится Яков Васильевич Перфильев - подполковник, обер-кригскомиссар, депутат Суздальского уезда в комиссии о сочинении нового уложения 1767 г. Там же названа его жена - графиня Александра Андреевна Толстая.

В тетради со схемами родословных Чулкова указана дата ее рождения - 1768 год. Следовательно, она не могла быть матерью детей Якова Васильевича Перфильева, в том числе и Екатерины Яковлевны, окончившей в 1785 г. Смольный институт. Вместе с тем нельзя не верить данным материалов, составленных авторитетным генеалогом Н.П. Чулковым, свидетельствующим, что графиня А.А. Толстая была женой Я.В. Перфильева.

Можно сделать единственно правильный вывод: Александра Андреевна Толстая была второй женой Якова Васильевича Перфильева. Это предположение позднее подтвердили материалы частного собрания другого в то время здравствовавшего московского генеалога Ю.Б. Шмарова, согласно которым женой Якова Перфильева, отца Екатерины Яковлевны, была Евдокия Гавриловна Багракова.

В том же отделе рукописных фондов Государственного литературного музея открываю объемистый том «Родословного сборника русских дворянских фамилий», составленного В.В. Руммелем и В.В. Голубцовым, с пометами, сделанными Н.П. Чулковым на полях страниц (экземпляр из библиотеки исследователя также хранится в отделе), и нахожу родословную графов Толстых. Перед Александрой Андреевной Толстой, уже упоминавшейся в родословной Перфильевых, указан ее брат Илья Андреевич, в 1811 г. бригадир, а затем тайный советник, умерший в 1820 г. (№ 158). (В родословной графов Толстых значатся два Ильи Андреевича, но только один из них жил в 1806 г. и, следовательно, мог быть отцом Гольц-Миллера-старшего.) В числе других детей у Ильи Андреевича был сын - граф Николай Ильич, отставной подполковник (№201). Далее в родословной росписи (№272) значится сын Николая Ильича и внук Ильи Андреевича - граф Лев Николаевич Толстой.

Выходило, что дети Ильи Андреевича Толстого: значившийся в родословной законнорожденный Николай Ильич и внебрачный Иван Иванович Гольц-Миллер-старший - были родными братьями, а их дети - великий писатель Лев Николаевич Толстой и полузабытый поэт-демократ Иван Иванович Гольц-Миллер младший - братьями двоюродными. Было от чего сойти с ума!

Прошло сорок лет, но я до сих пор отлично помню теплый летний вечер, когда вышел из подъезда дома на тогдашней улице Веснина (теперь она вновь зовется Денежным переулком), где в бывшей квартире А.В. Луначарского, ставшей филиалом Государственного литературного музея, размещен отдел рукописных фондов. Охватившие меня чувства были столь велики, что требовали необходимости немедленно поведать об открытии, только что сделанном мною, - столь невероятным оно казалось.

По счастью, человек, которому можно было рассказать об этом, мой Учитель и наставник Николай Иванович Либан, жил неподалеку. Я поспешил к нему, понимая, что по телефону что-либо внятно объяснить не смогу.

Перейдя Кропоткинскую и Метростроевскую улицы - ныне они вновь именуются Пречистенкой и Остоженкой, я свернул в сбегавший к Москве-реке извилистый переулок. Дойдя почти до его конца, прошел в ворота старого дома, стоящего на углу двух переулков, и оказался в уютном дворике, столь привычном для уходящей Москвы. 
Позднее двор станет меньше - его ограничит одна из выросших в последние годы престижных новостроек, оставив из большого числа только несколько деревьев, среди которых рябина и яблоня, достигшая крыши трехэтажного дома; никогда ранее я не видал такой высокой.

Войдя в знакомое парадное, в которое входил (и еще буду входить множество раз), поднялся на второй этаж и позвонил в квартиру Либана. Не переступая порога и даже забыв от волнения поздороваться с хозяином, открывшим мне дверь и удивленным неожиданным моим приходом, я выпалил:

- Николай Иванович, не сочтите меня сумасшедшим, но выходит, что Гольц-Миллер - двоюродный брат Льва Толстого!

Николай Иванович был удивлен и заинтригован:

- Как же это может быть? Заходите и рассказывайте!

- Отец Гольц-Миллера в письме Семевскому указывал имена своих родителей, - продолжал я, - граф Илья Андреевич Толстой и Екатерина Яковлевна Перфильева. Только что в Литературном музее я просматривал родословие графов Толстых. Выяснилось, что когда отец поэта Гольц-Миллера появился на свет, жил только один из Толстых, кто мог быть его отцом. В родословном сборнике значится, что у этого Ильи Андреевича Толстого был сын Николай Ильич, отставной подполковник, а у того, в свою очередь, сын Лев Николаевич, известный писатель, как там сказано. Вот так и выходит, что поэт Гольц-Миллер приходился двоюродным братом Льву Толстому.

Если мой официальный руководитель отнесся к найденным сведениям скептически, то Николай Иванович расценил их иначе. Вместе с ним была написана тщательно продуманная и аргументированная статья, озаглавленная «“Произведен был в немцы”. О происхождении И.И. Гольц-Миллера», которая увидела вскоре свет в академическом журнале «Русская литература». Завершалась статья выводом: «Таким образом, можно считать установленным, что И.И. Гольц-Миллер старший приходится дядей Л.Н. Толстому, а поэт И.И. Гольц-Миллер - двоюродным братом великому русскому писателю. Однако никаких отношений между этими людьми не существовало - они не были даже знакомы».

Факт родства И.И. Гольц-Миллера и Л.Н. Толстого признан в научных кругах и входит в статьи о Гольц-Миллере в биографических словарях русских писателей.

Восстановление биографии Гольц-Миллера старшего было интересно не только само по себе, но по той роли, какую оно сыграло в формировании характера его сына - поэта-революционера. Следует отметить, что любовь к литературе тот бесспорно воспринял от отца, на протяжении всей жизни стремившегося пополнить полученное в юности образование, много читавшего и неплохо владевшего пером. Наибольший интерес представляют его статьи мемуарного характера. Помимо главы неопубликованных записок, присланной в редакцию «Русской старины», нам известны его статьи о поэте-сыне, а также воспоминания о поэте первой четверти XIX в. М.В. Милонове, позднее опубликованные в этом журнале.

- Вы глупый человек, Алеша, - сказал как-то мне Николай Иванович, - не хотите закончить диссертацию.

- Но что даст ученая степень? - возразил я. - Она ведь не прибавит ни ума, ни знаний.

- Но она придаст вам значимость, поможет приобрести авторитет в научном мире. 
Я осмелился заметить, что мой Учитель и сам не защитил диссертацию, однако это не помешало ему стать преподавателем университета.

- Но у вас, в отличие от меня, нет научной школы, - ответил он.

Тогда я не нашелся, что возразить. У Николая Ивановича была школа, и какая - ведь он окончил аспирантуру ИФЛИ! Его учителями были А.И. Ревякин, В.Ф. Переверзев, М.Н. Сперанский, Г.Н. Поспелов - ученые, имена которых были знакомы мне по солидным научным трудам, ими написанным

Однако благодаря Учителю я стал причастен к научной школе, созданной им. И ныне с гордостью могу сказать:

- Я ученик Николая Ивановича Либана!

\section{ЛИТЕРАТУРА}

Корнеев А.В. Поэт революции И.И. Гольц-Миллер // Известия АН СССР. Серия литературы и языка. 1978. Т. 37. №6. С. 522-532.

Неопубликованные стихи И.И. Гольц-Миллера / Предисл. и примеч. А.В. Корнеева // Русская литература. 1980. №2. С. 183-194.

Корнеев А.В. «Произведен бы в немцы». О происхождении И.И. Гольц-Миллера // Русская литература. 1985. № 1. С. 189-195.

\section{RE F E RE N CES}

Korneev A.V. The Poet of the Revolution I.I. Goltz-Miller. Izvestia of the Academy of Sciences of the USSR. A series of literature and language. 1978. Vol.37. No 6, pp. 522-532.

Unpublished poems by I.I. Goltz-Miller / Introduction and comments by A.V.Korneev. Russkaya Literatura. 1980. No 2, pp. 183-194.

Korneev A.V. "Was Named the German". About the Origin of I.I. Goltz-Miller. Russkaya Literatura. 1985. No 1, pp. 189-195.

Сведения об авторе:

Алексей Вениаминович Корнеев, Историк русской литературы XIX века член Союза писателей РФ
Aleksey V. Korneev,

The Historian of Russian Literature of the $19^{\text {th }} \mathrm{c}$.

Member of the Union of Writers of the Russian Federation

korneev-kav@mail.ru 